\title{
Urdimento
}

Revista de Estudos em Artes Cênicas

E-ISSN: 2358.6958

\section{CELAS E ELAS: um resgate das memórias de experimentações sentidas em espaços de cárcere feminino no Presídio Regional de Joinville}

Jéssica Michels

\section{Para citar este artigo:}

MICHELS, Jéssica. CELAS E ELAS: um resgate das memórias de experimentações sentidas em espaços de cárcere feminino no Presídio Regional de Joinville. Urdimento, Florianópolis, v. 3, n. 39, nov./dez. 2020.

DOI: http:/dx.doi.org/10.5965/14145731033920200303 
CELAS E ELAS: um resgate das memórias de experimentações sentidas em espaços de cárcere feminino no Presídio Regional de Joinville

\author{
Jéssica Michels ${ }^{1}$
}

\begin{abstract}
Resumo
Este texto narra as experiências vivenciadas por uma fotógrafa feminista no projeto [Celas] e Elas: [des]montagem teatral sobre mulheres e cárceres. O projeto teatral foi realizado em 2019 por Daiane Dordete e Samira Sinara com reeducandas do Presídio Regional de Joinville, com subsídios do Sistema Municipal de Desenvolvimento pela Cultura - SIMDEC/2016. Uma produção da Cia VAi! - Núcleo de Pesquisa em Artes Cênicas (Joinville/SC). A exposição "Para além das celas" foi produzida com fotografias realizadas por Jéssica Michels durante as oficinas de teatro com as reeducandas do Presídio Regional de Joinville através do projeto Teatro com mulheres em privação de liberdade. Este texto toma a liberdade de ser escrito como um relato fluído e autêntico de uma experiência fotográfica com reeducandas do sistema prisional feminino na cidade de Joinville.
\end{abstract}

Palavras-chave: Presídio feminino. Fotografia. Presídio Regional de Joinville.

CELAS E ELAS. a rescue of the memories of the experience felt in the female prison spaces of Joinville Regional Prison

\begin{abstract}
This text narrates the experience of a feminist photographer in the project [Celas] e Elas: [des]montagem teatral sobre mulheres e cárceres. The theatrical project was realized in 2019 by Daiane Dordete and Samira Sinara with inmates of the Regional Prison of Joinville, with support from the Sistema Municipal de Desenvolvimento pela Cultura - SIMDEC/2016. It was produced by Cia VAi! - Núcleo de Pesquisa em Artes Cênicas (Joinville/SC). The exhibition "Para além das celas" was produced with photographs made by Jéssica Michels, during the theater workshops with inmates of the Regional Prison of Joinville through a project called Teatro com mulheres em privação de liberdade. This text takes the liberty of being written in such a way as to be a fluid and authentic account of a photographic experience with prisonersin the female prison system in the city of Joinville.
\end{abstract}

Keywords: Female prison. Photography. Joinville Regional Prison.

${ }^{1}$ Fotógrafa, artista visual, performer e produtora cultural. Graduanda no curso de Direito pela Universidade Federal de Santa Catarina, UFSC. Ativista política na luta feminista, movimento LGBT+ e defensora dos direitos humanos. michelsfotografia@gmail.com 
CELAS E ELAS. un rescate a las memorias de la experiencia vivida en los espacios carcelarios femeninos de la Prisión Regional de Joinville

\section{Resumen}

Este texto relata las experiencias de una fotógrafa feminista en el proyecto [Celas] e Elas: [des]montagem teatral sobre mulheres e cárceres. El proyecto teatral fue realizado en 2019 por Daiane Dordete y Samira Sinara con reeducandas de la Prisión Regional de Joinville, con subsidios del Sistema Municipal de Desenvolvimento pela Cultura - SIMDEC/2016. Una producción de la Cia VAi! - Núcleo de Pesquisa em Artes Cênicas (Joinville/SC). La exposición "Para além das celas" fue producida con fotografías de Jéssica Michels, durante los talleres de teatro con reeducandas de la Prisión Regional de Joinville a través del proyecto Teatro com mulheres em privação de liberdade. Este texto se toma la libertad de ser escrito de tal manera que sea un relato fluido y auténtico de una experiencia fotográfica con reeducandas del sistema penitenciario femenino de la ciudad de Joinville.

Palabras clave: Prisión de mujeres. Fotografía. Prisión Regional de Joinville. 
Pensar nesse exercício para um relato de experiência sobre as vivências da minha participação como fotógrafa no projeto [Celas] e Elas: [des]montagem teatral sobre mulheres e cárceres me lembrou de várias situações que se mesclam no debate e que juntas explicam a narrativa de onde estou. E gostaria de compartilhar para ilustrar esse caminho.

As primeiras memórias são das histórias que ouvi, ainda na pré-adolescência, no começo dos anos 2000, contados pela tia que visitava o seu companheiro na época que estava preso; sobre o processo de vigilância daquela época, das práticas humilhantes a que ela e muitas outras mulheres eram submetidas na inspeção. Ficar de cócoras, sem roupas íntimas, em cima de um espelho, para que as agentes penitenciárias verificassem se havia algo.

Também recordo da primeira vez que pude entrar num espaço de privação de liberdade. Neste caso, em julho de 2017, quando ainda era acadêmica de Jornalismo, e um colega de turma me convidou para fazer a cobertura fotográfica para uma reportagem ${ }^{2}$. Naquela ocasião, entrei nas instalações de trabalho da penitenciária industrial de Joinville, pude visitar as salas de aula e também a biblioteca, onde entrevistamos e fotografamos uma mulher trans que estava em situação de cárcere; e que essa pessoa ainda era sexada para o sistema penal como homem, afinal, não há ala feminina na penitenciária industrial, e, portanto, essa mulher trans, que não havia passado por retificação de identidade, muito menos uma cirurgia de transgenitalização; era lida para o sistema penal assim, como macho, e, por causa disso, teria o direito de estar na penitenciária. Ao contrário, se fosse reconhecida como mulher, só poderia estar alocada na ala feminina do presídio regional de Joinville, um local que eu sabia ser bem mais tensionado, tanto em questões físicas de estrutura, como nos processos da vigilância e atrito entre as facções criminosas. Naquela época, solicitamos oficialmente entrar também no presídio, mas todas as tentativas foram frustradas.

\footnotetext{
2 “Travesti presa em penitenciária masculina fala sobre preconceito e ressocialização". Texto: Alex Sander Magdyel; Foto: Jéssica Michels. Revista Eletrônica do Curso de Comunicação Social do Bom Jesus/lelusc (Revi). Disponível em: http://www.ielusc.br/aplicativos/wordpress_revi/travesti-presa-penitenciariamasculina-joinville/. Acesso em: 15 out. 2020.
} 
Essas eram minhas relações e percepções sobre cárcere; localizando um debate sobre diferentes prédios, espaços físicos institucionais. Presídio. Penitenciária. E por onde os debates de gênero que transicionavam no sistema criminal.

Em linha cronológica, percebo uma coincidência. Essa visita na penitenciária ocorre próximo do momento em que recebi o convite da atriz Samira Sinara para ser fotógrafa no projeto sobre teatro com mulheres em privação de liberdade, com a diretora Daiane Dordete. No caso, a linha cronológica do trabalho de Samira e Daiane com esse tema é bem mais extensa. Todavia, vale citar que eu já havia encontrado uma intersecção com meu trabalho fotográfico anteriormente. Em 2012, levei minha câmera fotográfica despretensiosamente para assistir uma apresentação do espetáculo Celas da Cia.VAil-núcleo de pesquisa em artes cênicas, com atuação da Samira Sinara e direção de Daiane Dordete. Portanto, é interessante ser chamada exatamente para ser fotógrafa, de modo oficial, um tempo depois para a continuação daquele primeiro trabalho cênico.

Figura 1 - Celas, 2012. Direção: Daiane Dordete. Atuação: Samira Sinara. Foto: Jéssica Michels

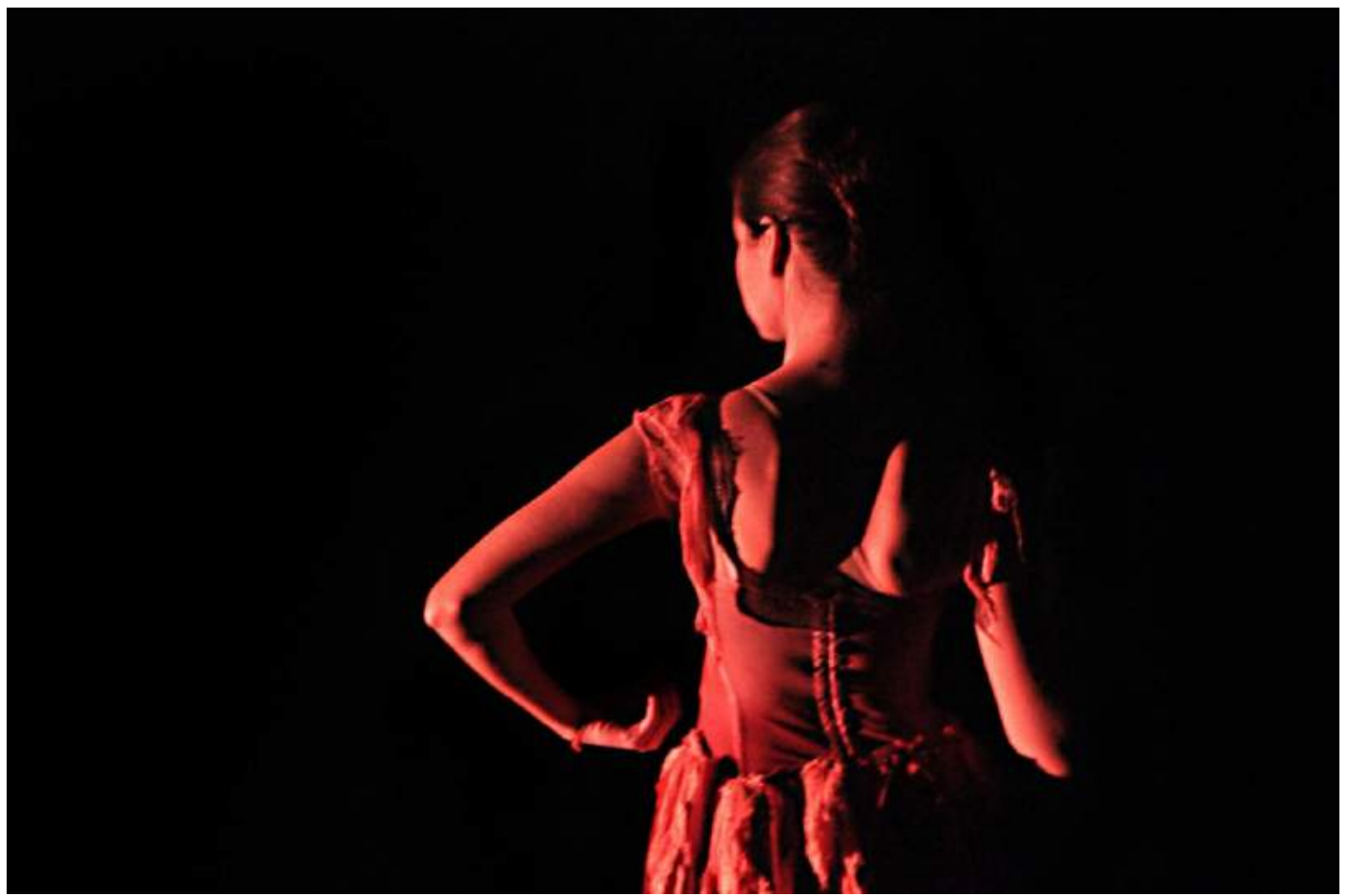

Fonte: Arquivo pessoal da autora, 2012 


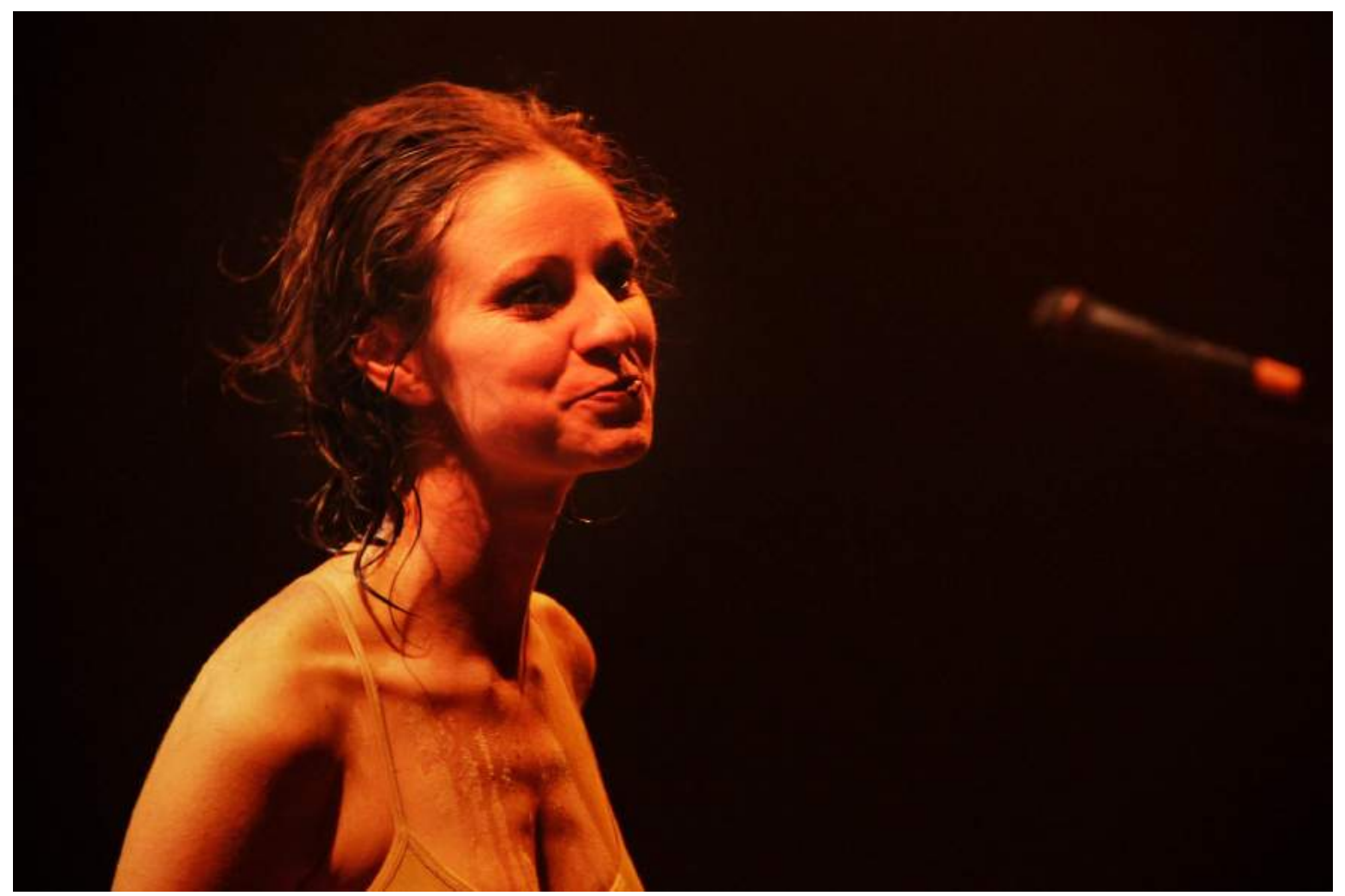

Fonte: Arquivo pessoal da autora, 2012

Entrar no presídio não foi fácil. E estou aqui ainda relatando sobre questões físicas. O projeto foi realizado no primeiro semestre de 2019, mas já estava em produção anos antes. Além da agenda do edital SIMDEC (Sistema Municipal de Desenvolvimento pela Cultura) de 2016, no qual foi contemplado, com cartas de anuência da direção do presídio e também do juiz João Marcos Buch, titular da 3.a Vara Criminal e Execuções Penais da comarca de Joinville, precisamos acompanhar uma sequência de burocracias e autorizações para entrar na ala feminina do presídio, passamos por um longo processo de adaptações das datas junto com a psicóloga do presídio, que é a responsável por todas as atividades pedagógicas da instituição e com o novo aval da direção do presídio. Isso durou anos.

10 de fevereiro de 2019. Essa é a data da primeira visita. Não pude levar minha câmera profissional porque recebemos comunicado na véspera que a direção não 
havia autorizado, porque não estava inteiramente por dentro do projeto e julgou que seriam "somente aulas de teatro, e que se precisasse de fotos, as agentes carcerárias poderiam tirar”. As burocracias já citadas acima. Cheguei às 9 h e fui a uma casinha que fica do lado de fora do sistema prisional. É uma grande sala de visitas e nas paredes há muitos comunicados e memorandos oficiais sobre os procedimentos de visitação. Percebi que há proibições específicas para mulheres, sobre as vestimentas. Aliás, percebi que eu só enxergava mulheres na sala. Eram 99\%. São as mulheres, designadas pelo patriarcado ao papel de cuidado, que visitam homens e mulheres em situação de cárcere. Todas elas se vestiam igual: calça de moletom cinza e camisa branca. As crianças também. E eu lembrei na hora de uma crônica ${ }^{3}$ do próprio juiz que citei acima sobre o estigma da marca social. Sou a única que vestia roupas comuns. Vou à primeira guarita e digo que sou parte de um projeto de teatro. A segurança, de empresa terceirizada, abre o portão do outro lado, onde passam os carros. As visitas passam por uma porta menor. Ela pede meu documento e liga para a psicóloga para confirmar minha entrada. Assim, entro na guarita para passar na máquina de scanner, a "caixa nobreak", como as agentes chamam.

Nesse momento eu sigo pela sala do outro lado e vejo uma esteira por onde passam os alimentos trazidos pelas visitas. Vejo também duas guardas, também de empresa terceirizada, abrindo todas as embalagens e colocando em sacos plásticos transparentes. Eu recebi uma chave e coloco meus pertences, minha bolsa e meu celular, num pequeno arquivo com chaves simples. Esse arquivo é identificado como propriedade da OAB - Subseção Joinville. Confesso que achei irônico usar um desses compartimentos reservados para os advogados da Ordem, agora que sou estudante de Direito na UFSC. Depois disso me apresento às agentes que usam uniforme preto, e então entro numa grande câmara escura, que também tem uma esteira. Preciso olhar fixamente para a câmera do scanner e manter meus braços levemente afastados e pernas abertas também. Já sinto que sou fichada. Eu não tinha noção que estava sendo vigiada até aquele momento.

"A Estrela de Davi" - Texto de João Marcos Buch. Revista Pazes. Disponível em: https://www.revistapazes.com/a-estrela-de-davi/. Acesso em: 15 out 2020. 
As agentes são tranquilas no trato comigo, sinto que acharam que eu era mesmo advogada. Fico na espera ao lado da porta final e vejo as agentes realizando todos os processos de verificação das visitantes. Eu não passei por isso. As visitas precisam retirar os chinelos e dobrar, precisam balançar os cabelos, precisam mostrar a língua, mesmo passando pelo scanner. Para elas, as agentes são mais sérias e burocratas. De fato, com o tempo, isso foi confirmado. A diferença de tratamento comigo e com as atrizes professoras, que éramos tratadas com sorrisos e até conversas informais, e a rigidez na fala e na direção de ordem para as visitantes.

Entre o primeiro portão e a sala de aula, eu preciso passar por 12 portas, portões, grades. Doze. Subo por outra grade, diferente da subida das visitantes, que ainda ficam mais um tempo numa casinha de sala de espera, que desemboca no estacionamento do setor administrativo. Sou orientada a entrar na primeira porta, onde fica a recepção. E fico sentada numa antessala aberta, onde tem cafezinho e quatro cadeiras de espera, e uma mesa pequena com um computador. Era uma salinha da OAB. Durante todo o projeto, fiquei nesta sala esperando e esperando todas as cinco vezes que estive no presídio, seja por cinco minutos ou por duas horas.

Figura 3 - Presídio Regional de Joinville. Foto: Jéssica Michels

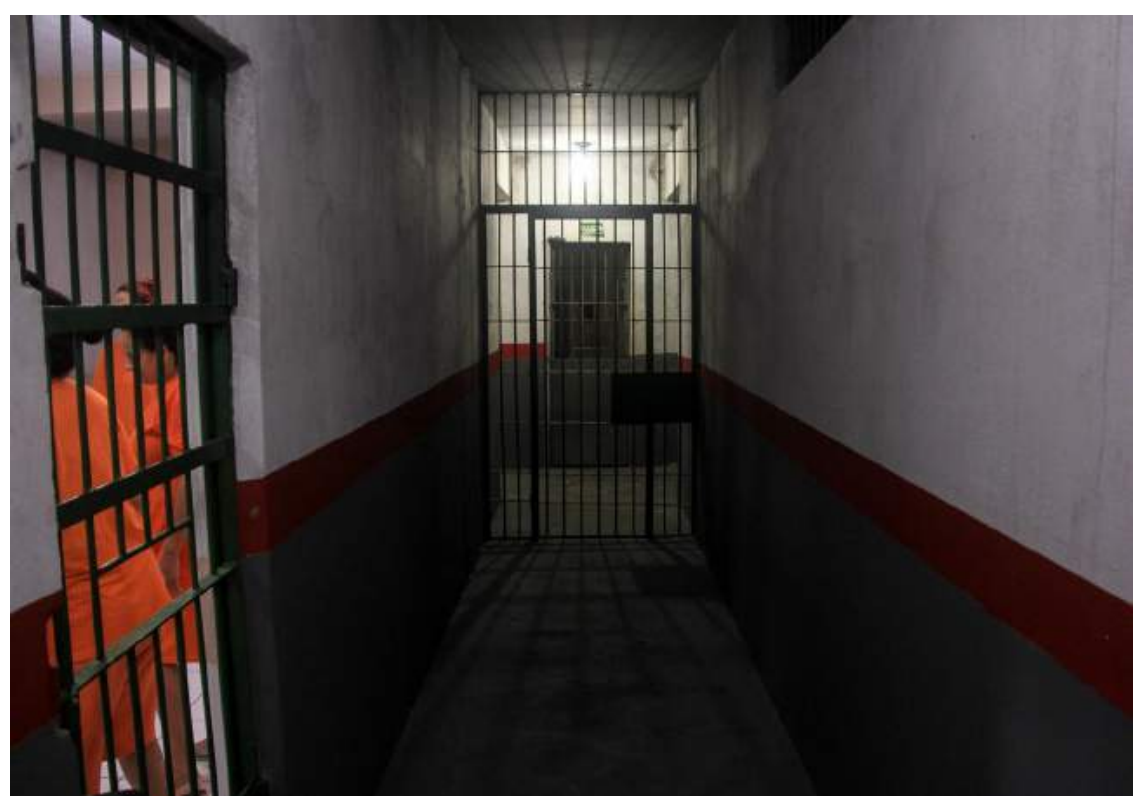

Fonte: Arquivo pessoal da autora, 2019 
Nesta primeira vez, em pouco tempo passou um agente e a recepcionista o interceptou para ele me levar à entrada do primeiro bloco. Saio novamente para o estacionamento e fui acompanhada até a terceira porta, onde tem mais uma antessala com cadeiras, mais um scanner, mas desses mais simples, e mais um guarda terceirizado. Sou orientada a ficar sentada. Chega mais um agente e desta vez com ele, as atrizes do projeto, que chegaram um pouco depois de mim. Esse agente pede para o guarda fazer uma ligação para alguém nos levar. Passamos o scanner, mais uma porta, dessa vez de metal, e agora sim, estamos dentro da unidade. Estamos de frente para uma área aberta e já posso ver alguns aprisionados com roupa verde clara, que sinaliza que eles trabalham e andam "livremente", ou seja, sem algemas. vi dois deles carregando lixos, eles seguem para uma lateral, e já vejo um homem andando no muro, fazendo a vigilância, ali está o "panóptico", citado em Michael Foucault, mas da maneira de onde vejo, ele faz uma vigilância por blocos quadrados. Depois descobri que esses homens são chamados de "muralha".

Entramos num bloco e no meio do corredor fomos colocadas na "sala dos guardas". Há duas mesas de escritório, muito papéis, bem "escritório". Um dos agentes está no telefone, num canto tem uma TV e em volta numa espécie também de antessala, ficamos sentadas nas cadeiras, são oito lugares. Tem cafezinho e água numa mesinha de canto. Nesse local vemos muitos agentes circulando e falando alto com os outros, todos nos olham e voltam a nos ignorar, como se não fôssemos problema deles. Eu fico um pouco ansiosa esperando qual será o agente que nos tomará como "sua responsabilidade" e finalmente seguiremos para a ala feminina.

Em algumas ocasiões, passaram por nós alguns detentos com vestimentas laranja, algemas nos pés e nas mãos. Não sabemos o que acontece. Muito do que escuto é formado por códigos e termos internos. O agente que estava no telefone é quem vai nos levar. Ao lado dele, na lateral, uma caixa de madeira com várias chaves penduradas, e embaixo dele, numa espécie de varal, cassetetes. Em cima da caixa, uma cruz simples de madeira. 
O agente nos leva então a uma nova galeria. E aqui começa a experiência do cárcere mesmo. Corredores escuros, muitas grades e cadeados até chegarmos à sala de aula. Quatro grades, com três cadeados cada. O molho de chave é enorme. E a sala de aula é uma decepção. Entre nós e as alunas, temos uma grade também. O agente nos deixa no espaço menor e nos tranca ali. Ele avisa que logo uma agente trará as detentas. E ele vai embora, fechando as quatro grades com três cadeados. Estamos presas.

Figura 4 - Registro das oficinas de teatro realizadas com reeducandas Presídio Regional de Joinville. Foto: Jéssica Michels

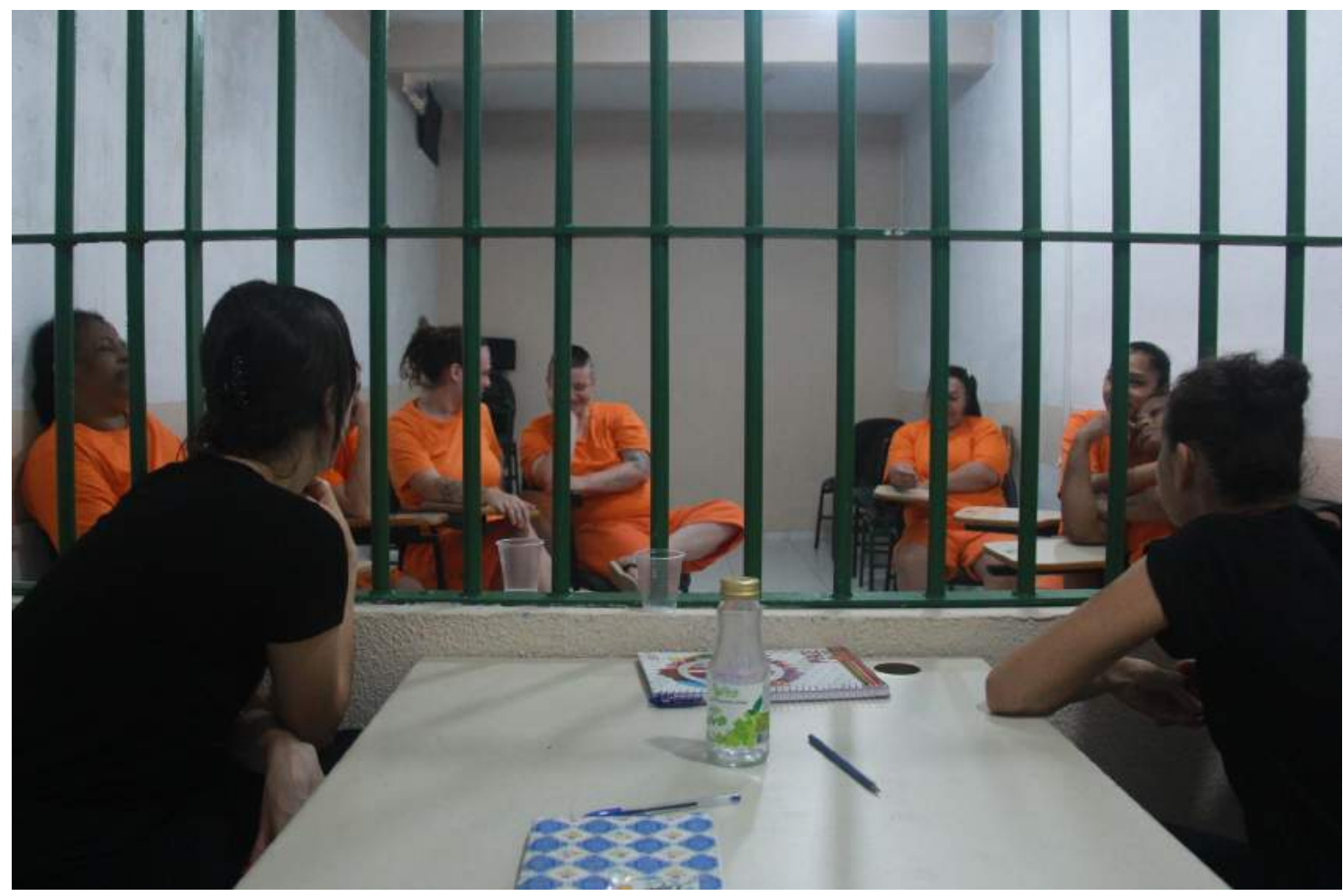

Fonte: Arquivo pessoal da autora, 2019

Já nesse primeiro momento, começo a tossir, sinto que tem um cheiro químico que me incomoda. Depois de meses, entendemos o motivo: há resquícios de spray de pimenta por tudo, parece impregnado nas paredes. Toda aula alguém fica com um ataque de tosse, desses que fazem sair lágrimas. A sala não tem janela, mas tem umas pequenas aberturas bem acima, de no máximo 30 
centímetros. Nesses espaços consigo ver coturnos andando, são as muralhas fazendo uma ronda constante e ininterrupta nos blocos/galerias/alas.

A agente penitenciária chega e abre a grade da sala onde elas permanecem, separadas de nós. Elas entram em fileira e permanecem em fileira mesmo na sala. Entram de cabeça abaixada, mãos para trás, mas sem as algemas. Seus corpos domesticados, parecem ser arqueados, devido ao processo disciplinizador. O ensino do teatro é baseado em atividades corporais e de voz. E foi, por vezes, dolorido compreender a dificuldade de libertar aqueles corpos das algemas invisíveis.

Figura 5 - Registro da oficina de teatro realizada com reeducandas Presídio Regional de Joinville. Foto: Jéssica Michels

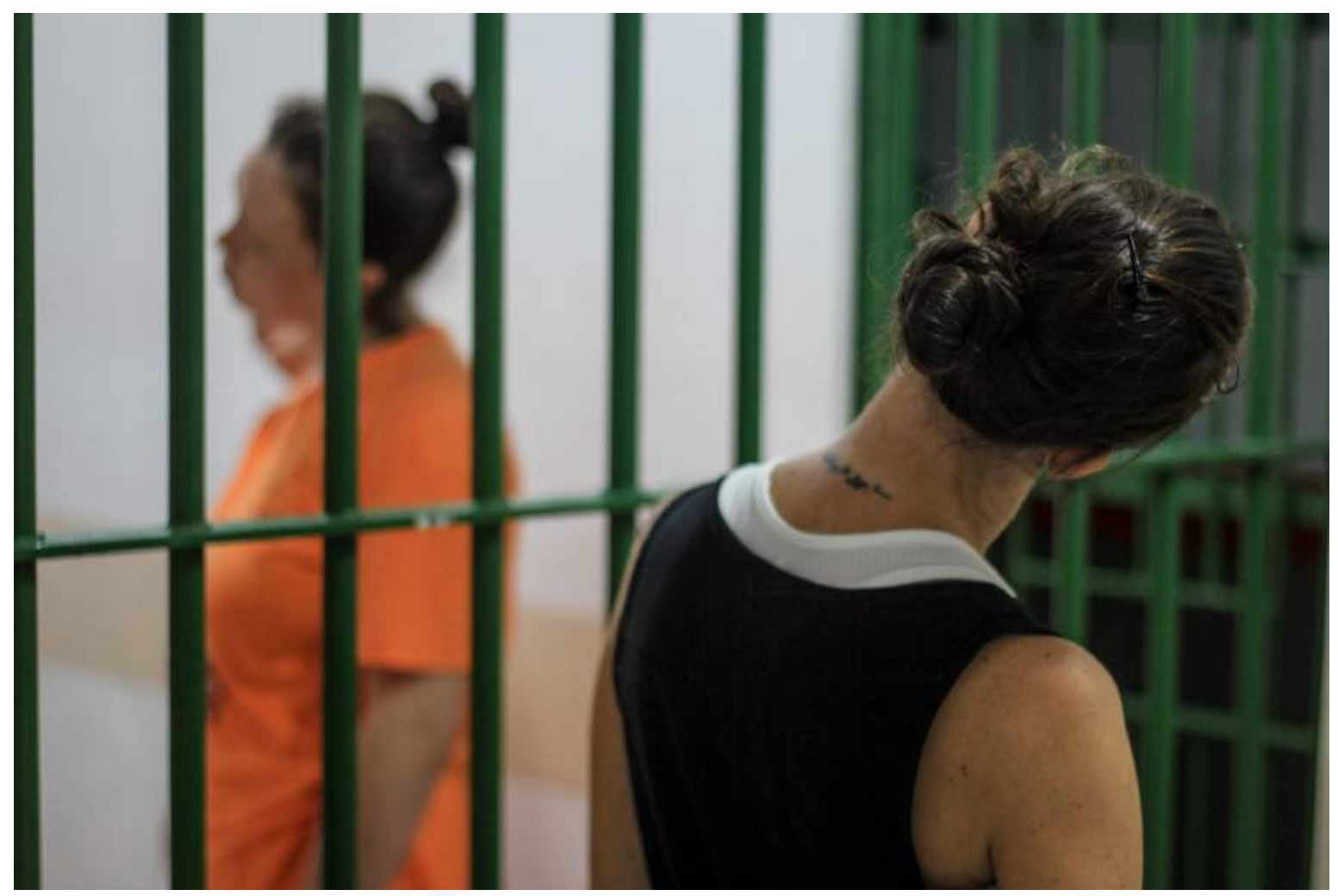

Fonte: Arquivo pessoal da autora, 2019

Na minha apresentação para as alunas, expliquei que era fotógrafa e pedi autorização verbal delas já para registrar as próximas aulas. Mas também citei que era estudante de Direito. No fim da aula, elas vieram coladas na grade pedindo para eu "olhar o processo delas". Estou nas primeiras fases do curso. Nem sei explicar a angústia 
que senti com esses pedidos de ajuda, porque não consigo mensurar o que seria a angústia de estar no lugar delas. Eu fiquei em cárcere por apenas três horas e não "estive" presa.

O processo de contagem me desesperava. A prisão é uma grande prática de contagem. Sistema criminal que conta corpos, corpos que têm números (no uniforme de algumas tinham sequência numérica). E pessoas que contam seus dias de sentença.

Ressalto isso porque na apresentação, muitas delas falavam de números. Dos artigos que colocaram elas nesse espaço, do tempo que elas já cumpriram e dos anos, meses e dias que faltavam de suas sentenças e, em algumas situações, de quantas vezes estiveram presas.

Figura 6 - Registro da oficina de teatro realizada com reeducandas Presídio Regional de Joinville. Foto: Jéssica Michels

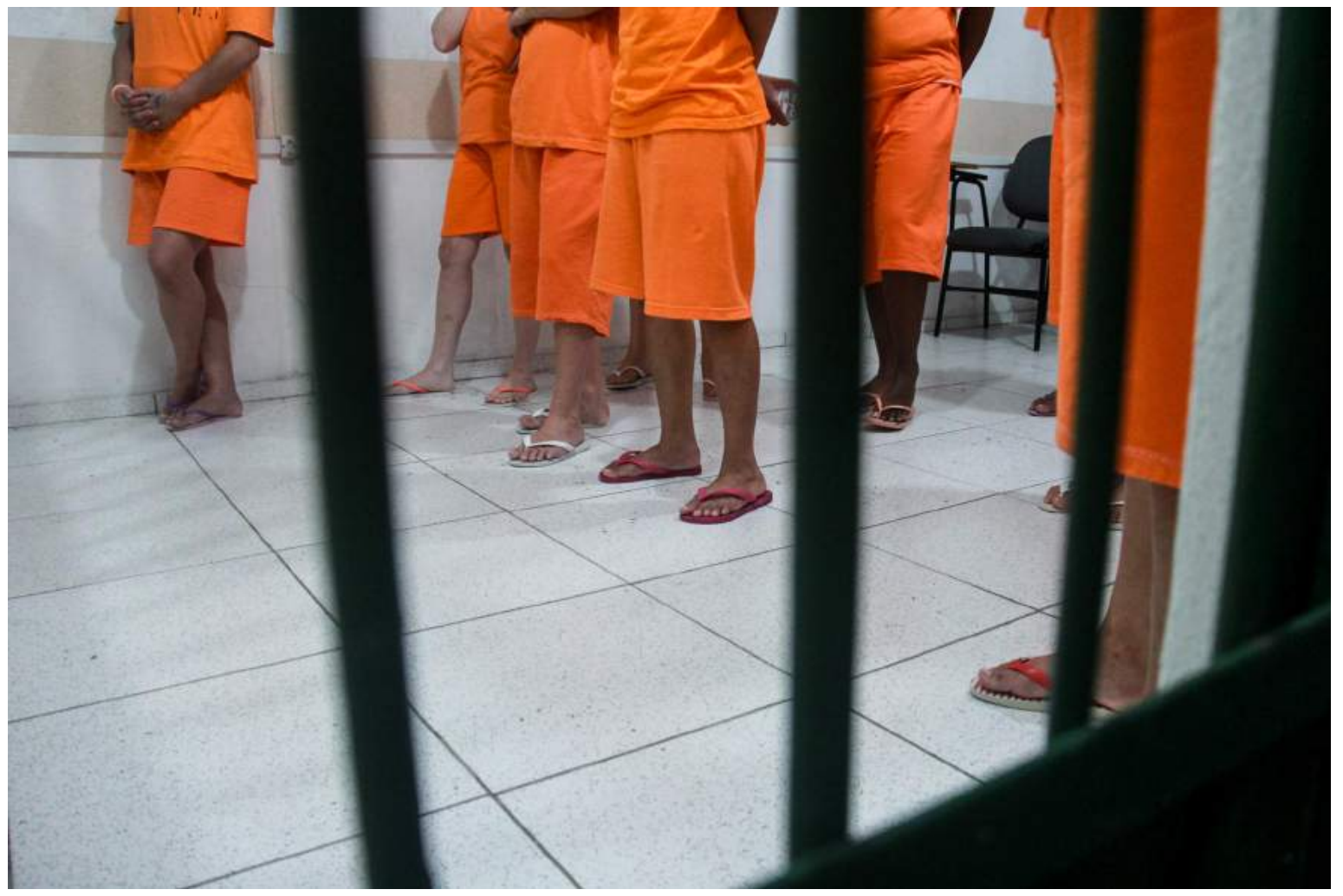

Fonte: Arquivo pessoal da autora, 2019

São 15 mulheres, a maioria se entende como branca. Um contraste em relação à população carcerária do Brasil, em que há uma necessidade de pensar 
a interseccionalidade, termo cunhado pela Kimberlé Creshaw, para pensar em todo o sistema, que vai ser atravessado por questões de gênero, raça e classe (Crenshaw, 2002). Mas aqui nesse grupo ficam refletidos de forma equivalente o crime que ampliou o número de mulheres encarceradas no Brasil: tráfico de drogas. Outra questão que gostaria de trazer para a reflexão e que uma grande parcela delas acabaram por se envolver com o tráfico por causa do marido ou namorado, quando esses foram presos. De modo a garantir a manutenção financeira e a sobrevivência do núcleo familiar, essas mulheres acabam por assumir o controle dos negócios desenvolvidos por seus companheiros.

Figura 7 - Registro da oficina de teatro realizada com reeducandas Presídio Regional de Joinville. Foto: Jéssica Michels

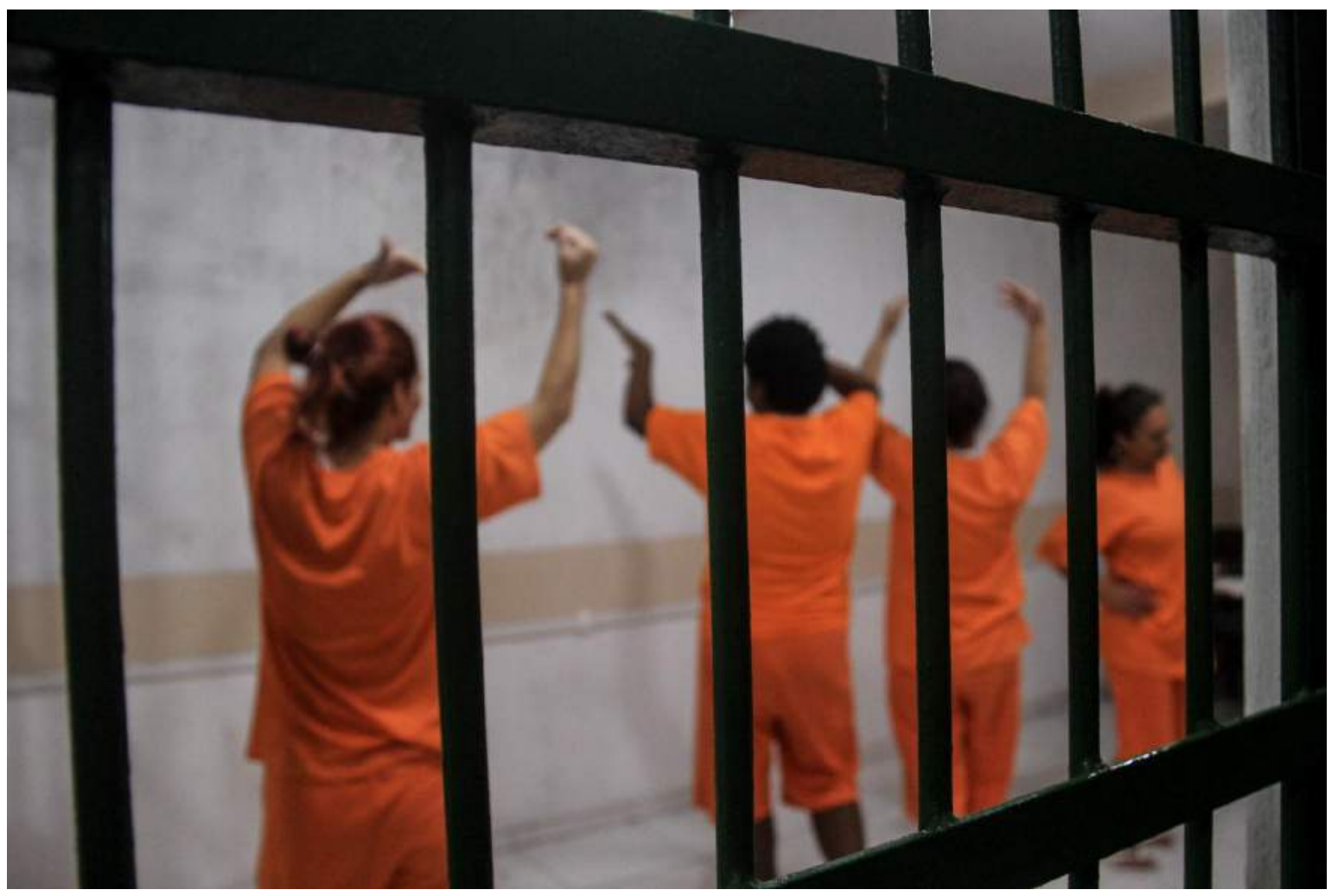

Fonte: Arquivo pessoal da autora, 2019

Foi notável o desconforto delas em fazer os exercícios das aulas, seja por vergonha de movimentar o corpo, seja pela falta de prática, seja mesmo a timidez da primeira aula. Do grupo, apenas uma dela já tinha feito teatro na igreja. Algumas 
inclusive já falaram que a motivação para estar ali não era a aula de teatro, é que a remissão de alguns dias é um processo de esperança, além de avançar no processo da contagem ${ }^{4}$. No fim da aula, todas comentaram que aquelas três horas foram bastante recompensadoras porque a atividade física até fazia elas "esquecerem" que estavam na prisão. Foi nesse momento que tudo fez sentido para mim.

As agentes vieram nos buscar e levar as alunas para as suas celas. Na ausência do celular, de não saber o horário, fato que inclusive dificultou a nossa divisão de atividades corporais e de canto. Despedimo-nos apressadas com um até logo. Eu passei pelas quatro grades de três cadeados. Elas ficaram. E esse foi o primeiro dia.

Vou poupar esses extensos detalhes narrativos, mas julgo serem detalhes importantes porque falam também do meu "adestramento" corporal e comportamental para estar naquele lugar. Na segunda visita, dia 5 de abril de 2019, pude entrar com a câmera, porém fiquei duas horas até ser liberada para a sala de aula. Tive pouco tempo para registrar aquela manhã de aula. Apenas uns 40 minutos. Nesse dia, trabalhei com a lente $50 \mathrm{~mm}$ e fiz fotos desfocando bastante os corpos, os rostos e utilizando a grade interna da sala de aula como elemento para tapar/ esconder os rostos daquelas mulheres para não haver identificação. Fiquei um tempo me questionando sobre esse processo até desumanizador, isso de borrar digitalmente na edição, mas que garantia a dignidade delas do seu direito de não serem expostas publicamente.

Eu não estive em todas as aulas semanais ministradas por Samira e Daiane, exatamente porque avaliamos que a presença da câmera fotográfica poderia inclusive ser um inibidor das emoções e movimentos corporais. Então, em todas minhas aparições nas aulas tentei ao máximo me camuflar, não chamar atenção, mesmo que a câmera em si seja algo nada discreto. E me orgulho demais dos resultados das primeiras visitas para registro das aulas.

\footnotetext{
${ }^{4}$ As alunas que concluíram o projeto de teatro foram contempladas com alguns dias de redução da sentença.
} 
Mas houve um momento que isso não aconteceu. Teve um momento que fui presente demais, mas ainda dentro do meu trabalho como fotógrafa. Numa das aulas, no dia 24 de maio de 2019, tivemos convidados da UDESC, o professor Vicente Concilio e a aluna Caroline Vetori e também convidados da Universidade de Michigan, a professora Ashley Lucas e aluna Hanna Agnew. Nesse dia, pela quantidade de pessoas do nosso lado da grade, garantimos bastante movimentação e foi um momento muito divertido para as alunas. Um dia de muitos sorrisos, dancinhas e trocas. Não tive como me isentar. Estive junto, dancei, fiz os exercícios, brincamos todas.

Figura 8 - Registros das oficinas de teatro realizadas com reeducandas Presídio Regional de Joinville. Foto: Jéssica Michels

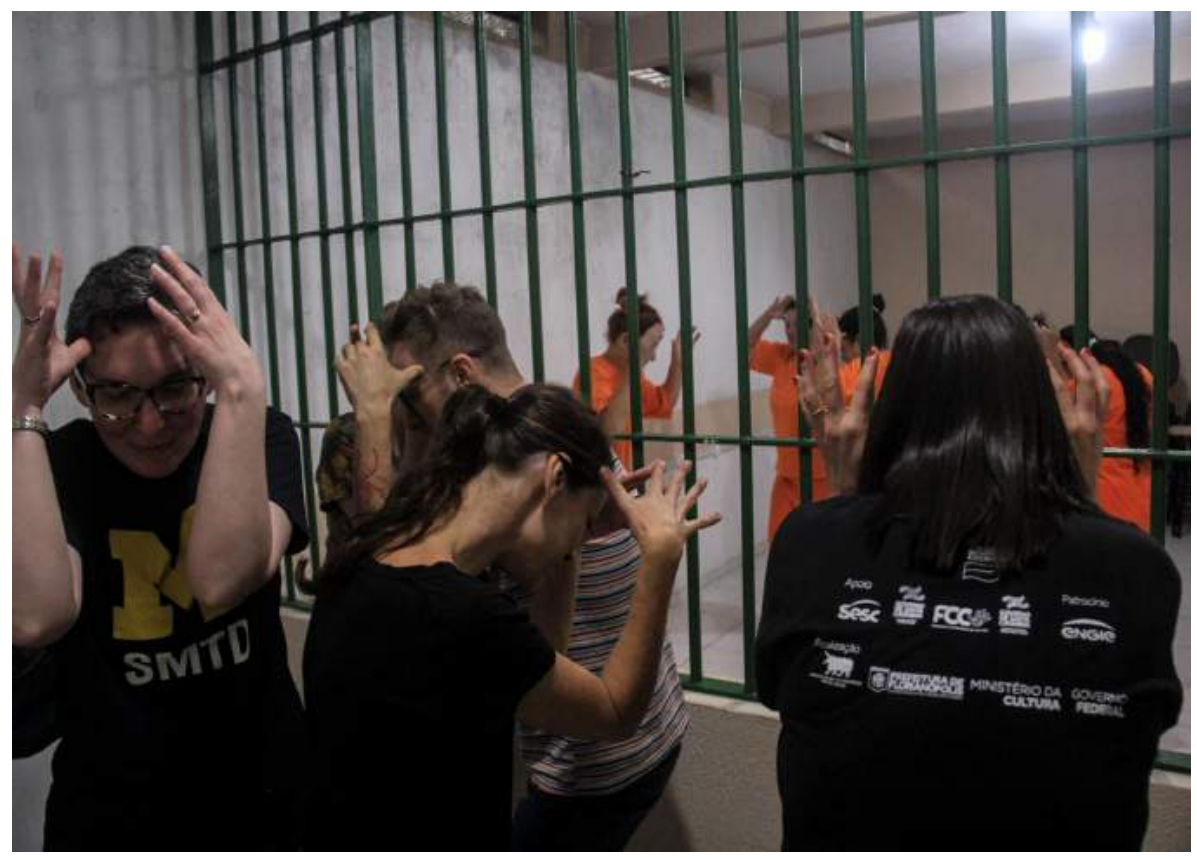

Fonte: Arquivo pessoal da autora, 2019 
Figura 9 - Registros das oficinas de teatro realizadas com reeducandas Presídio Regional de Joinville. Foto: Jéssica Michels

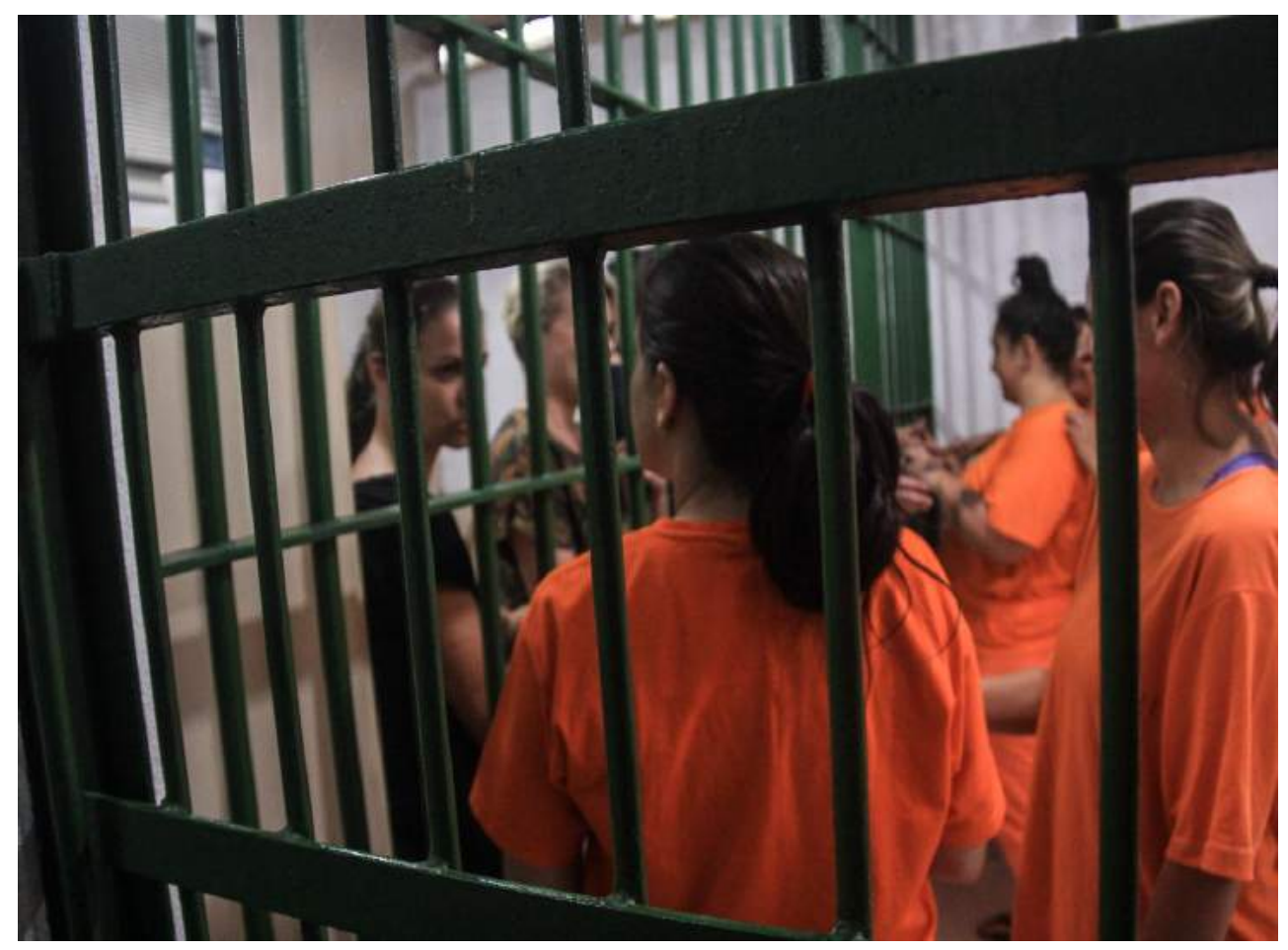

Fonte: Arquivo pessoal da autora, 2019

Uma das vivências mais impactantes foi num dia de atividades com objetos para trabalhar criações de cenas e textos. Para o protocolo, precisamos listar no dia anterior à visita, todos os materiais que entram no presídio. E mesmo com a lista verificada, o espelho não entrou. É vidro, não pode. Questões de segurança. Tentamos então pedir que fosse liberado um papel espelho. Negaram. E essa recusa causou muitas inquietações para mim. E para as alunas também, quando explicamos que tínhamos esse objetivo, de trabalhar com espelho. - É, não podemos ter espelho aqui, lamentou uma das alunas, uma das mais participativas. - E como vocês se veem? questionei. - A gente se enxerga uma no olho da outra. Assim. Sem performance e sem roteiro. Essa foi a resposta de prontidão. Na outra semana, levamos uma bandeja de prata. Passou no scanner, não questionaram. E pudemos fazer a experimentação daquele processo de reconhecimento. 
Figura 10 - Registro da oficina de teatro realizada com reeducandas

Presídio Regional de Joinville. Foto: Jéssica Michels

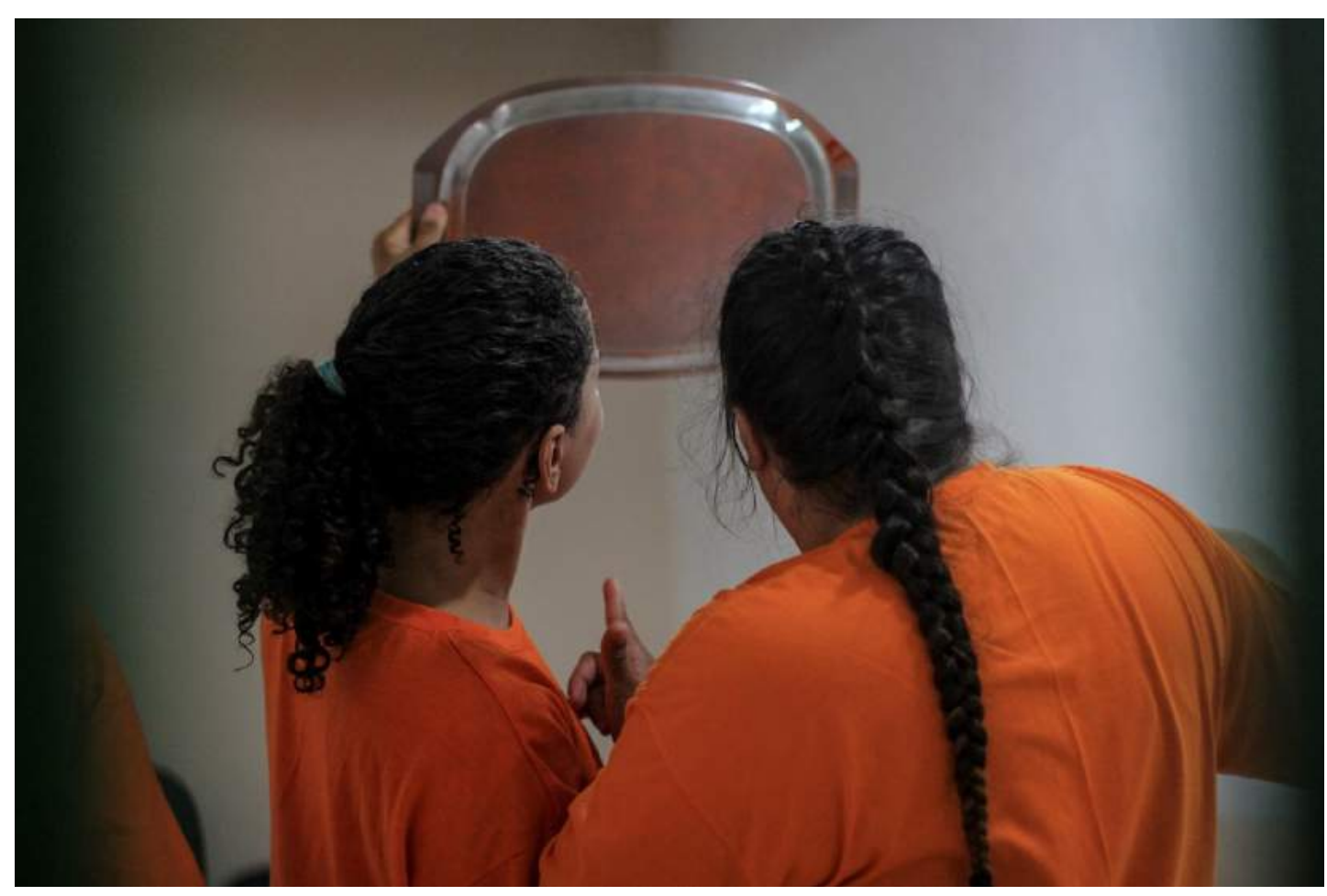

Fonte: Arquivo pessoal da autora, 2019

Então, propus a ação mais importante do meu trabalho enquanto fotógrafa. Arrisco. Decidi que fotografaria elas. Fotos de rosto, de corpo todo, com pose de balada, mão na cintura, com biquinho de beijinho. Uma a uma, frente a frente. Coloquei a lente padrão, a 18-200 mm, que passava pela grade e pude registrar todas elas sem marcas, sem grades. Uma a uma, mostrei as fotos da câmera, segurei nas mãos e escutei seus lamentos, seus sorrisos nervosos e seus choros. Algumas delas não se viam há anos. O choque da revelação, os comentários de que emagreceu, de que engordou, do cabelo que estava assim, da pele estava de tal aspecto.

Parece que nada me preparou para essa situação. Quase uma terapia intensiva em que eu era a pessoa que acolhia as lágrimas. Enquanto fotografava, Samira e Daiane conversam com elas sobre esse processo de identidade com o se ver no espelho. - Como é que eles (o sistema) esperam que a gente melhore 
aqui dentro, se fazem a gente quem a gente é? Assim, de novo, sem roteiro. Apenas dito. Revelado. Questionado. Das análises prontas. Da reflexão imediata.

Figura 11 - Registro da oficina de teatro realizada com reeducandas

Presídio Regional de Joinville. Foto: Jéssica Michels

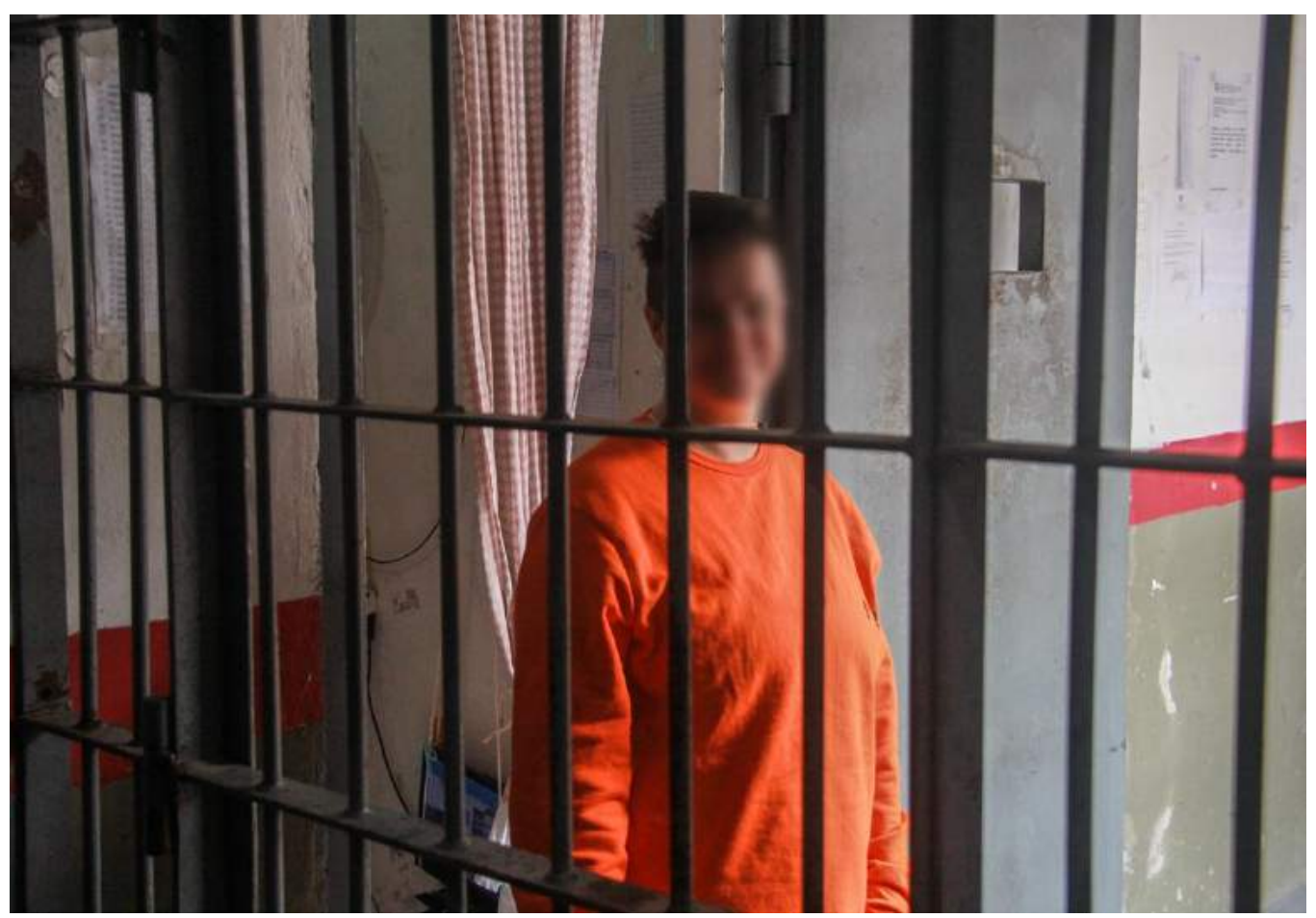

Fonte: Arquivo pessoal da autora, 2019

Depois, todas essas imagens foram deletadas do cartão de memória. Afinal, em algumas ocasiões, na saída das atividades, minha câmera era inspecionada e eu precisava mostrar as imagens gravadas para um supervisor. Esta foi minha manobra arriscada. Quando minha ferramenta de trabalho, uma câmera digital Canon 60D, pode permitir uma relação de reconhecimento sobre quem a gente é, sobre quem elas são. E sobre o que o Estado, a Justiça e o Sistema representam para a vida daquelas mulheres que precisam do olhar do outro para lembrar e saber que estão vivas. 
Recomendações de leitura

CRENSHAW, KIMBERLÉ. Documento para o encontro de especialistas em aspectos da discriminação racial relativos ao gênero. Florianópolis: Revista Estudos Feministas [online]. vol.10, n.1, p.171-188, 2002. Disponível em: https://doi.org/10.1590/S0104-026X2002000100011. Acesso em: 15 out. 2020.

FOUCAULT, Michel. Vigiar e Punir. história da violência nas prisões. Petrópolis: Editora Vozes, 1987.

Recebido em: 15/10/2020

Aprovado em: 01/12/2020 